\section{Кратки}

научни прилог

\title{
On Open Questions in Holocaust Education
}

\begin{abstract}
Even though recent decades have borne witness to an increased educational interest in teaching the Holocaust, academic stances on why the topic should be taught still vary significantly. The aim of this paper is to present teaching interventions that would help educators to navigate through one of the most important open questions in Holocaust education: the question of aims. Three Holocaust-related teaching interventions, which themselves use open questions as the basis for teaching and learning, are presented and analysed. The open questions, as the background, allow the educators to simultaneously shift between various teaching aims. The interventions addressing the question of heroes, victims and bystanders, causal analysis of the Holocaust, and the responsibility of the Allies for the escalation of the Holocaust, are arranged in such a way so as to lead students from their day-to-day knowledge, through historical concepts, finally ending up addressing more abstract concepts. The analysis draws on literature related to both Holocaust education and the teaching of controversial issues, and covers a range of topics; from practical to more philosophical.
\end{abstract}

Keywords: Holocaust education, history education, teaching aims, controversial issues, open questions.

\section{Introduction}

Hand (2008) terms a teaching question as controversial if it ensues different and opposing views whereupon none of them is being contrary to reason. Drawing on Robert Dearden, Hand (2008) terms this notion the epistemic criterion; teaching controversial topics, he notes, has an intended outcome for students to identify conflicting views on the same issue and comprehend their supportive arguments.

1 danilo.kovac.17@alumni.ucl.ac.uk 
One of the initial decisions that educators must make is to establish whether a question is closed or an open one, argue Hess and Gatti (2010: 21). The authors explain that the main characteristic of a closed question is that there is only one correct answer to it, whereas an open question ensues varying but legitimate answers. Teachers might have their own opinions about the right answers, but they ought to provide students with such type of instruction that is free from imposing the educators' own views and ideologies (Hess and Gatti, 2010: 22). Given that teaching controversial and open questions could share certain similarities, these two terms will be used interchangeably throughout this paper.

The aim of this paper is to present teaching interventions that would help educators to navigate through one of the most important open questions in Holocaust education: the question of aims. Three Holocaust-related teaching interventions, which themselves use open questions as the basis for teaching and learning, are presented and analysed. The open questions, as the background, allow the educators to simultaneously shift between various teaching aims. The interventions addressing the question of heroes, victims and bystanders, causal analysis of the Holocaust, and the responsibility of the Allies for the escalation of the Holocaust, are arranged in such a way so as to lead students from their dayto-day knowledge, through historical concepts, finally ending up addressing more abstract concepts. The sequence of lessons, selected to rehearse and develop historical knowledge first is in line with Foster (2020), emphasising the importance of historical knowledge aquisition for general understanding of the Holocaust. Accordingly, the first lesson addressing the questions of perpetrators, victims and bystanders aims to develop historical knowledge of basic Holocaust related terms in all of their complexity. Historical knowledge as the basis should be further expanded in the next two lessons, accompanied by more complex sociological and philosophical concepts. While designing the lesson plans, I endeavored to follow the recommendations that teach- ing controversial issues ought to be non-directive, and the teacher should assist students in developing their own opinions on one of the accepted solutions (Hand, 2008).

The three lessons are intended to accompany high school history curricula, paying particular attention to Holocaust education. The planned duration of the each lesson is 1 hour and 30 minutes. My experience says that the interventions are particularly relevant to the International Baccalaureate Diploma Programme educational settings. Apart from that, the teaching activities are applicable to extracurricular activities and history clubs, given that many curricula do not allow several hours for teaching the Holocaust. Before addressing the Holocaust through open questions, students are expected to be familiar with the main aspects of Jewish culture and life before the Holocaust, history of antisemitism in Europe, the main concepts of Nazi ideology, as well as the course of the Second World War in Europe.

It is suggested that teachers address their national context. The third lesson is suitable for the analysis of what a particular country has done to prevent the escalation of the Holocaust, and to what extent it was possible to do more. This kind of approach is possible within certain national contexts.

The teaching interventions are designed to serve as the basis for achieving various teaching aims, and should be complemented by educators in accordance with the specificities of their students and curricula. Nonetheless, not all of the educational aims are included. It might be sensible to assume that literature, citizenship, music and art classes have the potential to compliment educational aims presented in this paper. This approach would be in line with Chapman (2020). He argues for the benefits of approaching the Holocaust through different disciplines, comparing them to distinct "optics", or ways of (students') perception (p. 54). Unfortunately, an inter-curricular approach does not exist in many schools, and each of the teachers has to find the way of shifting between different teaching aims. 


\section{Contrasting aims in Holocaust education}

Discussions on the Holocaust education aims saturate the attitudes between and among teachers, guideline recommenders and education researchers as well. Academics and educators, as well as the public, are divided into several points of views on the appropriate aims of the Holocaust teaching. For one strand of thought, teaching unique historical realities within a strictly contextualised time era of the Nazi regime should be the main purpose of the Holocaust education. For those holding the opposite view comparative, ethical, and intellectual frameworks of teaching the Holocaust have a primary role in the Holocaust curriculum (Gray, 2015).

The debates on the aims of Holocaust education are on-going among education researchers themselves. Novick (1999) argues that no lesson on everyday knowledge can be attained through the Holocaust teaching; the circumstances in which the Holocaust occurred had been so extreme that they were removed far from the threshold of what constituted everyday life. Rather, "more meaningful lessons can be learned from the behaviour of normal Americans than from Nazi officers during extreme circumstances", asserts Novick (1999:245).

In a similar vein, Kinloch (2001) argues that any goal of the Holocaust education which is not directly linked with developing students' knowledge on specific historical events should be regarded as inadequate. In his paper, Kinloch (2001) offers a view on the futility of invocation of historical memory as a protection against future violence when, matter-of-factly, the genocides in Cambodia and Rwanda occurred after the Holocaust.

In line with Kinloch (2001) and Novick (1999), Salmons (2010) argues against moral or "activist" agenda of teaching the Holocaust. Salmons (2010: 57) highlighted that, unless students internalised the historical details and comprehended why the historical event happened, visiting locations of the former concentration camps is not only educa- tionally useless, but potentially detrimental. He further explains that real learning does not take place by working with symbolically charged terms - such has become the word "Holocaust" - in order to convey the profoundly detrimental aspects of racism and extreme intolerance. Consequently, demonstrating an understanding of the absorbed knowledge, through connections made between facts is far more crucial for students' intellectual development than asking them how they feel upon learning a historical event (Salmons, 2010: 62-63).

Considering the arguments above, I would say that teaching the Holocaust as per Salmons' (2010) recommendations fulfils the criteria of Michael Young's theory of "powerful knowledge" $(2015,2013 a, b)$. In their paper, Young and Muller (2014) emphasised that schools should deliver academic, or the so-called powerful knowledge, which surpasses the conceptions made by students in their everyday life. Delivered through specialised school subjects, the powerful knowledge is systematic, specialised, and superior to the knowledge students acquire in their everyday life, explain Young and Muller (2014). It goes without saying that acquiring academic knowledge on the extremely complex topic of the Holocaust is poles apart from students' everyday knowledge.

The idea of teaching the Holocaust chiefly for the purpose of academic knowledge is irreconcilable with the views of many researchers. They claim that the Holocaust education should primarily aim at promoting civic and moral virtues (Short, 2003; Landau, 1989). Ronnie Landau elaborates on the reasons for including the Holocaust in the National Curriculum for its capacity to "civilise and humanise our students and... has the power to sensitise them to the dangers of indifference, intolerance, racism and the dehumanisation of others" (Landau, 1989: 20). In a similar vein, Short (2003: 281) argues that effective teaching of the Holocaust has contributed to the prevention of genocide in the last fifty years. Weimar Republic, according to the author, serves as 
an example to students to realise that existing racism shall not simply fade away and its emergence should be therefore carefully dealt with. The author believes that there should be a link between the fact that highly educated Nazi dignitaries (with doctoral degrees) made up half of the Wannsee Conference memberships, and the schools' expected main focus on students' moral development. Short (2003: 285286) maintains that students who study the Holocaust have an opportunity to learn the consequences of peoples' obliviousness and turning a blind eye as well as the consequences of unrestricted discriminatory speeches.

It would be sensible to assume that the care for others, as explained by Landau (1989) and Short (2003), fulfils the criteria of what Reiss and White (2014) define as a flourishing life. According to Reiss and White (2014), education should enable students to have an autonomy and lead a fulfilling life. Furthermore, they see the purpose of education in enabling students to care for others by means of "helping others to reach their goals, respecting their autonomy and being fair, friendly and cooperative" (Reiss and White, 2014: 79). It is evident that the care for others corresponds with Short's (2003) argument for teaching the Holocaust for the prevention of racism. Congruence of their aims is even more evident as Reiss and White consider the role of school in the light of "widening students' moral sensitivity" (Reiss and White, 2014: 79), and further in correspondence to what Short (2003) and Landau (1989) regard as the purpose of the Holocaust education. Yet another point by Reiss and White (2014), that school education should nurture a liberal democratic norms and standards of society, is in line with the Short's (2003) and Landau's (1989) notions on prevention of all types of discrimination by Holocaust teaching.

In the absence of clear instructions, educators have to find their own methods to navigate through the aims of Holocaust education. This challenging task requires a sound instructional approach which strongly develops students' academic knowledge while simultaneously encourages them to reconsider their moral dilemmas. The lesson plans designed to help the educators navigate through the Holocaust teaching aims are presented in the following sections.

\section{Lesson plans}

In the absence of clear instructions, educators have to find their own methods to navigate through the aims of Holocaust education. Three teaching interventions that would help educators to navigate through the aims of Holocaust education are presented and analysed in this section.

\section{Lesson 1 - Perpetrators, victims, bystanders, and silent heroes}

The lesson, outlined in Table 1 attempts to reconcile the contrasting aims of Holocaust education. I designed the lesson plan drawing on my experience at the Museum of Silent Heroes and the Buchenwald Concentration Camp, as well as reflecting on the literature on the recent debates on the Holocaust education.

Many researchers have explained how a poor historical knowledge of the Holocaust can be an obstacle to achieving all other educational aims (Bloxham, 2009; Browning, 1992; Cesarani, 2005; Foster, 2020; Kershaw, 2008) Accordingly, Lesson 1 starts with revisiting the main concepts about the running of the Nazi state, which is necessary for the main part of the Lesson 1. 
Table 1 Lesson 1 (Lesson plan)

\begin{tabular}{|c|c|c|}
\hline & Teaching/learning activities & Learning objectives \\
\hline Starter & $\begin{array}{l}\text { Explain the running of the Nazi camp } \\
\text { system in Europe and the role of differ- } \\
\text { ent kinds of police forces. }\end{array}$ & $\begin{array}{l}\text {-To understand how the Nazi state machine } \\
\text { was keeping control of the state. }\end{array}$ \\
\hline Main & $\begin{array}{l}\text { Ask students to fill in the table below for } \\
\text { each of four dilemmas and discuss with } \\
\text { them their choice. }\end{array}$ & $\begin{array}{l}\text {-To consider the options available for indi- } \\
\text { viduals caught in moral dilemmas developing } \\
\text { understanding of historical context. } \\
\text { - To develop understanding of the complex } \\
\text { terms: victims, bystanders and perpetrators. }\end{array}$ \\
\hline Plenary & $\begin{array}{l}\text { Provide students with other necessary } \\
\text { information they ask for, or indicate a } \\
\text { relevant source of information. }\end{array}$ & $\begin{array}{l}\text {-To further capture students' imagination for } \\
\text { their project or enquiry. } \\
\text {-To developing understanding of historical } \\
\text { context. }\end{array}$ \\
\hline Homework & $\begin{array}{l}\text { Explore two biographies of Silent He- } \\
\text { roes }^{*} \text { of your choice. } \\
\text { https://www.gedenkstaette-stille-helden. } \\
\text { de/gedenkstaette/ }\end{array}$ & $\begin{array}{l}\text {-To acquire knowledge of onerous individu- } \\
\text { als and consider motivation for their heroic } \\
\text { deeds. } \\
\text {-To supplement understanding of the histori- } \\
\text { cal context }\end{array}$ \\
\hline
\end{tabular}

* Ordinary German citizens who risked their lives to help endangered Jews.

The teaching plan designed for the main part of the lesson is given in Box 1. The pedagogical approach which begins with a non-historical content (Box 1 - Dilemma 1), is in line with the recommendations by Young and Muller (2014), claiming that teaching should begin with students' day-to-day experience which is gradually supplemented by academic knowledge. I recommend this reflective learning exercise for more than a few of its educational benefits.

Firstly, in order to put themselves in the position of these ordinary German citizens, who, in all likelihood, had experienced personal dilemmas, students have to draw on their powerful knowledge of the relevant historical context. By engaging with academic knowledge, students rehearse it and set the ground for further progress, which is in line with Foster's (2020) recommendation about the impor- tance of historical knowledge for further progression in studying about the Holocaust.

Secondly, I argue that reconsideration of this moral dilemma corresponds with the theory by Reiss and White (2014), stating that schools "can help students think about moral conflicts in their own lives and in the wider spheres" (Reiss and White, 2014: 79).

Thirdly, I ask students to emerge themselves in the given dilemma which will personalise the historical past and genuinely motivate them for learning about the topic. By exploring the thought-provoking biographies students are stimulated from the very outset of the lesson for examining the further historical content, which is in line with Harris' (2005) and Kitson et al. (2011) view, stating that an interesting opening is crucial for any historical enquiry. 
Fourthly, students themselves are encouraged to choose the course of further historical inquiry, as they are asked what other contextual information they need (Box 1, Table 2 - last column). In this context, Hammond (2011) describes the benefits of the pedagogical approach which follows students' preferences in historical enquiry.
Lastly, developing a proper understanding of the complex terms - perpetrators, bystanders and victims - is necessary for achieving both historical and moral aims. Salmons (2010: 10) warned against teaching the Holocaust without a nuanced and complex knowledge of these three terms. On the other hand, academics Dickinson and Lee (1978) were among the first to note that history, unlike many

\section{Box 1: Lesson one - Teaching/learning activities}

Students are supposed to fill in the table (Table 2) drawing on four dilemmas.

Table 2 Teaching/learning activities

\begin{tabular}{|c|c|c|c|c|c|c|}
\hline & $\begin{array}{l}\text { Possible } \\
\text { choices }\end{array}$ & $\begin{array}{l}\text { Positive } \\
\text { consequences }\end{array}$ & $\begin{array}{l}\text { Negative } \\
\text { consequences }\end{array}$ & $\begin{array}{l}\text { Thick the } \\
\text { choice you } \\
\text { would make }\end{array}$ & $\begin{array}{l}\text { Give two } \\
\text { reasons for } \\
\text { your choice }\end{array}$ & $\begin{array}{l}\text { What other } \\
\text { contextual } \\
\text { information } \\
\text { do you need? }\end{array}$ \\
\hline \multicolumn{7}{|l|}{ Dilemma 1} \\
\hline \multicolumn{7}{|l|}{ Dilemma 2} \\
\hline \multicolumn{7}{|l|}{ Dilemma 3} \\
\hline Dilemma 4 & & & & & & \\
\hline
\end{tabular}

\section{Dilemma 1}

A poor woman stole some fruit from the market stall to give it to her hungry son. The owner of the market noticed her action and threatens to call the police. The woman explained that her son is hungry and she has no money.

\section{Dilemma 2}

A Jewish prisoner is told to become a capo (a person responsible for a group of inmates) in the Buchenwald Concentration Camp. In that way he would be responsible for caring out technical Nazi orders within his group of inmates. Acceptance of this position will increase his chances of survival for some time.

\section{Dilemma 3}

An unknown Jewish man nocked on the door of the German secondary school teacher Gustav Muller in Berlin in 1940. If Gustav accepts to give him a shelter in his home, he will put in danger his life and the safety of his family.

\section{Dilemma 4}

A Jewish doctor nocked of the door of the German secondary school teacher Gustav Muller in Berlin in 1940, asking for shelter for her daughter. Gustav knew the doctor very well, as she went out of her way five years ago, to help Gustav's son, who suffered life-threatening injuries in a traffic accident. If Gustav accepts to give her a shelter in his home, he will put in danger his life and the safety of his family. 
other disciplines, lacks its specialised language relying on the terms from everyday communication instead. Perpetrators, victims and bystanders are everyday terms which in the context of the Holocaust take a very complex meaning. Apart from Dickinson and Lee (1978), many other academics emphasised the link between the understanding of historical processes and the nuanced knowledge of the specialised language (Chapman, 2003; Lee and Shemilt, 2009; Woodcock, 2005).

In sum, my response to the dilemma of appropriate aims of the Holocaust education is represented in the lesson design (Box 1), which simultaneously integrates an intellectual exercise led by historical facts and moral contemplation of their possible meanings for the current age. Nonetheless, the lesson design (Box 1 - Dilemma 3 and 4) is directly proportional to the levels and depths of acquired historical knowledge. The detected gaps in students' knowledge could be addressed in the course of the activity analysed in the next section, which is more focused on historical aims.

\section{Lesson 2 - The Holocaust causal analysis}

Given that historians operate with many interpretations of the causes of the Holocaust (Totten and Feinberg, 2016), it would be logical to assume that the issue meets the criteria of an open question. Consequently, this section, developed as Lesson 2 (Table 3), offers suggestions of how to deal with the topic in the classroom setting. Two pedagogical challenges are reported in this intervention. While the first activity - Causal Classification (Box 2) addresses the causal classification of the Holocaust, the second one - Weighing of causal importance (Box 3) pertains to determining the importance of each cause against both, the final outcome, and other cluster of causes.

Table 3 Lesson 2 (Lesson plan)

\begin{tabular}{|c|c|c|}
\hline & Teaching/learning activities & Learning objectives \\
\hline Starter & $\begin{array}{l}\text { Revision of the basic facts related to } \\
\text { the rise of Nazism and their policy } \\
\text { towards the Jewish population }\end{array}$ & $\begin{array}{l}\text {-To revisit the basic knowledge of emergence and } \\
\text { escalation of antisemitism in Germany }\end{array}$ \\
\hline Main & $\begin{array}{l}\text { Students should complete Tasks } 1 \\
\text { and } 2\end{array}$ & $\begin{array}{l}\text {-To develop a sophisticated understanding of the } \\
\text { causes of the Holocaust. }\end{array}$ \\
\hline Plenary & Students should discuss their choices & $\begin{array}{c}\text {-To improve critical thinking } \\
\text {-To practice making choices explaining reasons } \\
\text { behind their decisions } \\
\text {-To judge other opinions and practice discussion } \\
\text { - To address the question of justice and acknowl- } \\
\text { edgement }\end{array}$ \\
\hline Homework & $\begin{array}{l}\text { Students should write a timeline of } \\
\text { causes of the Holocaust, determining } \\
\text { its chronological frame }\end{array}$ & -To revise chronology of the Holocaust causes \\
\hline
\end{tabular}




\section{Causal classification}

Many researchers have written on how to develop students' causal analysis in history education (Chapman, 2003, Chapman and Woodcock, 2006; Lee and Shemilt, 2009; Totten and Feinberg, 2016). From my perspective, Chapman's (2003) suggestion is the most appropriate, as each word in his causal classification clearly describes the type of cause applicable to the Holocaust. In his paper Chapman (2003) divided the causes into three categories and further worked them out by designing the subcategories.

However, to elaborate further on Chapman's (2003) classification, I suggest that students first write the causes on the cards and then assign the same causes to different headings (Box 2 - Students' tasks b) and c). In that way, students can relate to one cause as, for example, a trigger as well as an economic cause. It is likely that in this way students' perception of the Holocaust causes would be less rigid. Importantly, the reflexion on the categories ought to foster discussion.
Furthermore, I argue for more flexibility within the Chapman (2003) classification - which would potentially yield more educational benefits. In the light of this, students should be assigned the task to develop new causal categories on their own in addition to those given by the teacher (Box 2- Students' task d). For instance, one additional category can be the personal cause, i.e., Hitler's personal contribution to the Holocaust; another one can be the accidents where students may insert various causes, such as the Reichstag's Fire. It goes without saying that this activity may be a challenging task for many students. Nonetheless, dividing students into small groups may overcome this challenge as "the performance of the group is better than that of its best member" (Mercier and Sperber, 2011: 63). This phenomenon, which the same authors called Assembly bonus effect, may be relied upon in implementation of this learning task. Likewise, given that developing causal categories requires creativity, it is expectant that two or more students who work towards the same goal are more like-

Box 2: Lesson 2 -Teaching/learning activities of developing causal classification

Students' task:

a) Write on the cards the causes of the Holocaust

b) Assign your causes into the subcategories of the content heading.

c) Assign as many causes into the time and role subcategories.

d) Design your own categories assigning to it as many causes as you can.

\begin{tabular}{lll}
\hline Category & Subcategory & Place for cards \\
\hline Content & Economic (causes) \\
& Cultural \\
& Ideological \\
Time & Short-term \\
& Long-term \\
Role & Precondition \\
& Trigger \\
- & - \\
& - \\
\hline
\end{tabular}


ly to use reasoning and dialogue in order to reach consensus, rather than merely vote on the best solution. This manner of reaching an agreement is exactly what Walton (1990) strongly recommends as the best approach for this type of argumentative dialogue. He terms it the 'Planning Committee', and reasserts that the benefits of this approach lie in fostering discussion. This is also in line with what Mercier and Sperber (2011) term exploratory talk, emphasising the importance of its role in the classroom.

\section{Weighing of Causal Importance}

In order to gear students towards a more complex historical causal analysis, Chapman (2003) drew on a teaching strategy named the Diamond Nine. Its objective was to enable students to assign importance to different causes. Accordingly, a cause placed at the top of the Diamond Nine has the strongest relevance for the final outcome. The shape of the diamond enables students to assign the importance of each cause in relation to other causes (Box 3).

In my view, the Diamond Nine has at least three educational benefits. The first one is to engage students in causal reasoning as they have to be prepared to argument placing each of the Holocaust causes in its designated place. This approach is in line with Hand's (2008) view, stating that by expos- ing students to the exercise of uncovering and examining facts educators optimise students' prospects of flourishing. He further writes that "engagement in practical and theoretical reasoning is both intrinsically rewarding and the most effective means of securing a wide range of individual and social goods" (Hand, 2008: 218).

The second benefit arises from the fact that one group of students complete the Diamond Nine exercise in dialectic opposition to other groups. This practice follows Hand's recommendation that educators should enable students to "judge candidates for belief against the evidence or arguments in their support" (Hand, 2008: 218). Hand's (2008) recommendation is in line Hess and Gatti's position that educators should encourage students to "weigh competing arguments based on their merits" (Hess and Gatti, 2010: 20). Consequently, by completing the Diamond Nine through a dialectic approach, students are stimulated to analyse, assess and adopt other claims should they find its evidence epistemically adequate. Lastly, the third benefit of the Diamond Nine is in line with Hess and Gatti' s (2010) argument, that discussing controversial issues students are becoming better disputants. Information about the course of the teaching activity is presented in Box 3.

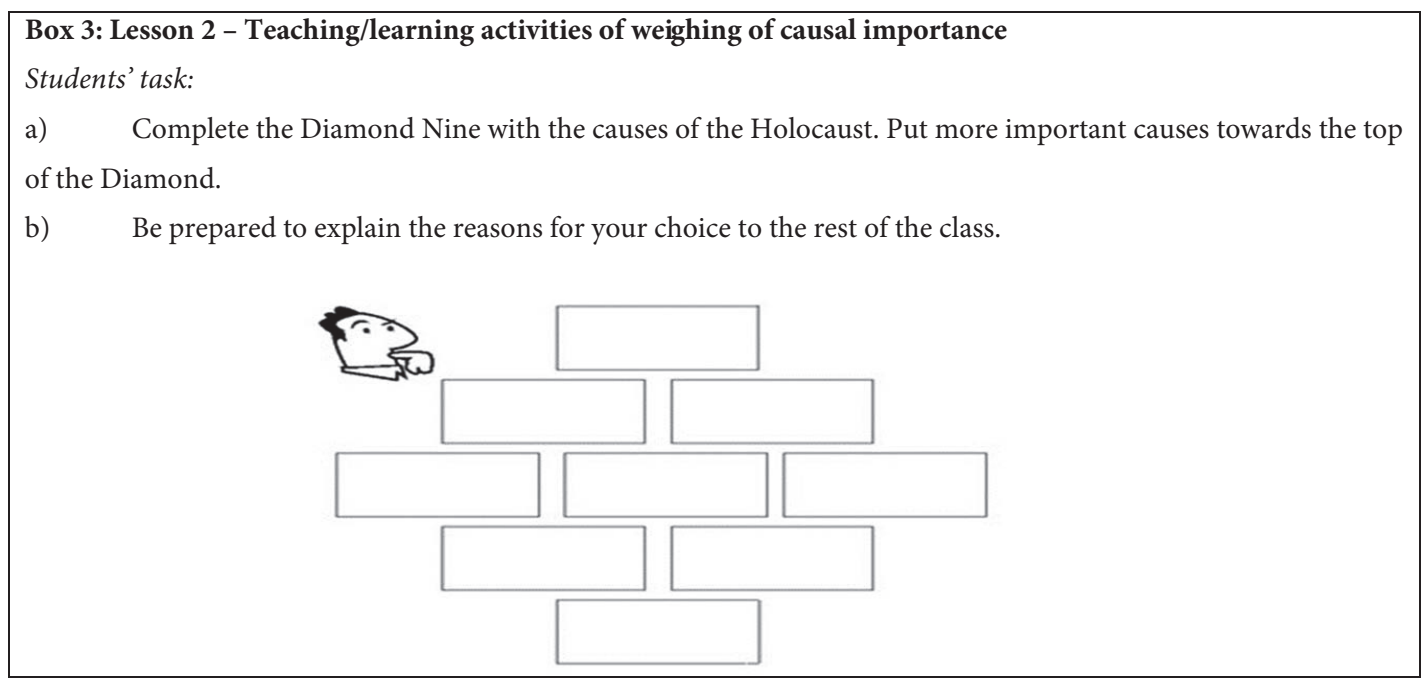


The completion of the task envisaged for this lesson will significantly develop and rehearse students' academic or powerful knowledge on the Holocaust causes, which is relevant to the historical aims of teaching the topic. Apart from that, students will have their debating skills improved as well as the capacity to make their own choices and explain reasons behind their decisions. In the world outside the classroom, this skillset, according to Reiss and White (2014), may help students lead a flourishing and fulfilling life.

One of the downfalls of this approach is that it can be time-consuming. Furthermore, developing additional categories within the exercise might foster unhistorical responses and inaccuracies. Even though the term "accident" is present in the pedagogy of historical causal analysis (Woodstock, 2011),
I suggest caution in its application as it might cause confusion, especially amongst the lower-performing students.

\section{Lesson 3 - The Allies' Responsibility for the Escalation of the Holocaust}

In their study, Oulton et al. (2004) emphasised that most teachers in England teach controversial topics through discussion. In the light of this, I suggest that teaching the question of the Allies' share of responsibility for the escalation of the Holocaust may be organised as a set of debates (Table 3 ). This kind of approach is in line with IHRA guidelines (2019: 32), arguing for discussions around the fact the (escalation of) the Holocaust was not inevitable. The benefits of this approach will be reviewed in this section.

Table 3 - Lesson 3 (lesson plan)

\begin{tabular}{|c|c|c|}
\hline & Teaching/learning activities & Learning objectives \\
\hline Starter & $\begin{array}{l}\text { Acquaint students with conflicting views about the } \\
\text { responsibility of the Allies for the escalation of the } \\
\text { Holocaust }\end{array}$ & -To consider different perspectives. \\
\hline Main & $\begin{array}{l}\text { Students engage in the first three phases of the } \\
\text { debate }\end{array}$ & $\begin{array}{l}\text {-To develop a sophisticated understand- } \\
\text { ing of historical context } \\
\text {-To envisage alternative scenarios } \\
\text {-To practice debating } \\
\text {-To normalise conflicting views }\end{array}$ \\
\hline Plenary & $\begin{array}{c}\text { A teacher states her opinion and answers students' } \\
\text { questions. }\end{array}$ & -To challenge authorities \\
\hline Homework & $\begin{array}{l}\text { Write an essay on the topic Allies should/not be } \\
\text { blamed for the escalation of the Holocaust }\end{array}$ & $\begin{array}{l}\text {-To rehearse the knowledge acquired in } \\
\text { the lesson. } \\
\text {-To coherently develop arguments. }\end{array}$ \\
\hline
\end{tabular}

Hand and Levinson (2012) argue that students defend the views they genuinely hold with more passion and meaningfulness. For the sake of this toolkit (Table 4), I would argue for the contrary, i.e., creating an artificial dialectical diversity. Students will find and interrogate arguments which will defend each side of the conflicting view (Table 4,
Stage 2). Having completed this, the teacher will ensure that students fully explain their own positions on the subject towards the end of the lesson (Table 4, Stage 3).

The lesson design (Table 4) engages students in the process of intellectual reasoning during which 
they also improve their skillsets. The reason I argue that students should suspend their judgements for as long as possible during the lesson is to prevent them from holding the same view they had developed beforehand (at the beginning or long before the lesson). "Reasoning should be even more biased once the reasoner has already stated her opinion., wrote Mercier and Sperber (2011: 67). Similarly, Oulton et al. (2004) warned against the pedagogical approaches which encourage pupils to prematurely form their stances on an issue. The same authors encourage "open-mindedness, a thirst for more information, and a willingness to change one's own mind" (Oulton et al, 2004: 505). Equally, Epley and Gilovich (2016) emphasise that people engage in a motivated reasoning in order to find arguments in favour of their preferred opinion; most people would welcome the facts that support their desired stance, while they would be much more sceptical of the evidence that supports contradictory stances. Consequently, if students express their view at the beginning of the lesson, they might not be sufficient- ly motivated to evaluate the historical evidence they are subsequently assigned with, and/or overly critical of contradictory arguments they are presented with. Siegel (1997) considers that educators' prime learning objective in respect to their students is to improve their reasoning skills. This idea, in conjugation with the Hand and Levinson's (2012) argument that students more effectively defend the views they genuinely hold, results in designing a lesson which does not impede students' acting on reason. Rather, it "help(s) students develop the ability to evaluate arguments and the probative force which putative reasons have and to encourage students to believe and act on the basis of reasons" (Siegel, 1997: 20).

Apart from debating presented historical facts, students are taught to respect the views different to theirs and tackle any discrepancy in opinion by entering a reasoned debate. This approach, overall, makes students better citizens, according to Haydon (2006), who claims that respect is an important and right attitude that one should have towards his/her fellow citizens. This form of respect is

\section{Table 4 - Lesson 3 Teaching activities}

\section{Debate topic}

Allies should/not be blamed for the escalation of the Holocaust

\section{Stage 1}

Students are expected to uncover arguments for the views assigned by the teacher and engage in a debate;

\section{Stage 2}

Students are expected to shift positions and find arguments for the opposing view followed by another round of a debate;

\section{Stage 3}

Students form and state their own opinions;

\section{Stage 4}

The teacher states arguments to the class and defends his/her position. 
not based on the comparison of one's own skills and knowledge to other's, but on individual regard for other persons. I believe that respecting each other's opinions by means of debating on historical questions is compatible with what Haydon (2006) calls a non-comparative respect. Naturally, criticising other peoples' opinions and stances is not incompatible with respecting their personality. Even though Haydon (2006) had in mind primarily the benefits of citizenship education when discussing this topic, I believe that for the Holocaust debate it can be equally beneficial.

\section{The role of teachers in Lesson 3}

I believe that the teacher should moderate debates to a certain level in order to encourage lively and constructive students' exchanges. As evidenced by Hand and Levinson (2012), debates tend to be conducted with a less argumentative power and analysis when teacher is entirely absent. Given that it is a historical debate, teacher should be responsive to promptly provide necessary historical facts and details and correct historical inaccuracies in order to enable smooth debating.

Discussing the role of teachers in greater detail, the question can be raised whether a teacher should disclose his/her personal opinions on the debate in question. The research by Oulton et al. (2004), conducted among English primary and secondary teachers, demonstrates that there is no consensus amongst educators on whether teachers should disclose their opinion on controversial questions. For example, the controversial question of racism entailed a close number of responses across the three optional answers: $29 \%$ of the questioned teachers said that would not disclose their personal opinion on a controversial question; 29\% designated that they were willing to disclose if asked, while $42 \%$ of them claimed that they would make their opinions clear. Education theory is equally marked by diverging opinions on this question. Thomas E. Kelly (1986) details four different possibilities while in favour of committed impartiality, that is, teachers disclose their opinions without trying to impose them on students. Kelly (1986) explained the potential risks of this approach given that teacher's opinion can influence students and hinder their reasoning. Moreover, the potential risk of influencing students' reasoning by teachers' opinion increases with the students being of younger age, according to Jerome et al. (2003) and Miller-Lane et al. (2006).

Notwithstanding the risks, I am inclined to accept Kelly's (1986) approach of committed impartiality (Table 4, Stage 4) for the following reasons. Given the lesson structure, teachers' opinions are less likely to influence students' opinions in the fourth stage of the class, when they have already formed and expressed their views. This approach is in line with Jerome and al. (2003: 73) claiming that "a teacher should only make their opinion known in a lesson where opinions are being developed and the exchange of opinions among students encouraged". Secondly, from a theoretical point of view, the topic of the debate is an open question itself, so the conflicting answers not be contrary to reason are expectant. With this theoretical explanation, I hope to diminish an influence of a teacher's position over the classroom and students' opinions. In this respect, Hand and Levinson (2012) emphasised that teachers are not authorities on matters of controversial issues. The third reason lies in accepting Siegel's (1998) and Kelly's (1986) point about teacher's honesty which is imperative for creating and sustaining a true learning environment. The learning environment which accommodates free and tolerant exchange of views naturally entails teacher's participation and input as well. Finally, the teacher's reasoning and depth of knowledge may elucidate some details over which students had doubts which do not substantially change their stances. At this stage of the lesson the students are already deeply engaged with the topic.

Along a similar line, I believe that educators should encourage students to challenge their own 
opinions; educators must be prepared to argument their opinions and even modify them if students present powerful counterarguments. With this approach, the teacher shall demonstrate that there is no discrepancy between what one says and what one does or, what Hayward (2009) calls, "the hidden curriculum" (Hayward, 2009: 61).

The debate on the Holocaust encourages students to examine and present multiple points of view on acquired historical facts by making connections between and among them. In this manner, students' capacities to effectively navigate within different segments of historical debate are enlarged.

For clarity, if the Allies were to prevent the escalation of genocide they could have intervened at multiple points in time. In turn, it would have produced different historical scenarios. The disadvantage of the intervention is that students are not given room to exchange their genuine arguments during the third stage of the lesson, as I believe that three debates on the same topic would be too much. Nonetheless, students can exchange arguments with the teacher in the fourth stage of the lesson.

For this lesson plan to be successfully applied, the following pre-conditions must be met:

- Students should already master certain levels of presentation skills.

- A friendly classroom environment is ensured, where students feel free to disagree.
- The teacher has given a thorough explanation of the term 'Ally' as the Holocaust started before the formation of the Alliances.

- The teacher must walk a carefully drawn line between students' disregard of 'The Allies' role in the Holocaust escalation' on one hand, and its overemphasis on the other, and intervene if necessary

\section{Final discussion}

In the absence of clear instructions, educators have to find their own methods by which to navigate through the aims in Holocaust education. A means of reconciling teaching aims can be to shift between different educational aims throughout the same lesson. Attempting to distance itself from the debates about the aims of Holocaust education per se, the paper presents a proposal for a sequence of lessons that would help educators to simultaneously combine several teaching aims, pertaining to students' rehearsal and improvement of historical knowledge, experiencing difficult dilemmas, personalising the past, formulating and assessing arguments, developing a sense of empathy. Furthermore, the sequence of lessons, leading students from their day-to-day knowledge through historical content and eventually reaching more philosophical concepts endeavours to improve debating skills and the reaching of compromises, and aims to normalize the existence of divergent voices.

\section{References}

- Bloxham, D. (2009). The Final Solution: A genocide. Oxford: Oxford University Press.

- Browning, C. (1992). Ordinary Men: Reserve Police Battalion 101 and the Final Solution in Poland. New York: Harper Collins.

- Callan, E. (2011). When to shut students up: Civility, silencing, and free speech. Theory and Research in Education, 9 (1), 3-22.

- Cesarani, D. (2005). Eichmann: His life and crimes. London: Vintage. 
- Chapman, A. (2003). Camels, diamonds and counterfactuals: a model for teaching causal reasoning. Teaching History, 112, 46-53.

- Chapman, A. \& Woodcock, J. (2006). Mussolini's missing marbles: simulating history at GCSE. Teaching History, 124, 17-26.

- Chapman, A. (2020). Learning the Lessons of the Holocaust: A Critical Exploration. In: Foster, S., Pearce, A. \& Pettigrew, A. (Eds.). Holocaust Education in the Twenty-first Century: Challenges and controversies (50-74). London: UCL Press.

- Dawidowicz, A. (1992). How They Teach the Holocaust. In: Kozody, N. (Ed.). What Is the Use of Jewish History? (65-83). New York: Schocken Books.

- Dickinson A. K. \& Lee P. J. (1978). History Teaching and Historical Understanding. London: Heinemann Educational.

- Epley, N. \& Gilovich, T. (2016). The Mechanics of Motivated Reasoning. Journal of Economic Perspectives, 30 (3), 133-140.

- Foster, S. (2020). To what extent does the acquisition of historical knowledge really matter when studying the Holocaust? In: Foster, S., Pearce, A. \& Pettigrew, A. (Eds.). Holocaust Education in the Twenty-first Century: Challenges and controversies (28-50). London: UCL Press.

- Gray, M. (2015). Teaching the Holocaust: Practical approaches for ages 11-18. Milton Park, Abingdon, Oxon; New York, NY: Routledge.

- Hammond, K. (2011) Pupil-led historical enquiry: what might this actually be? Teaching History, 144, 44-50.

- Hand, M. \& Revinson, R. (2012). Discussing Controversial Issues in the Classroom. Educational Philosophy and Theory, 44 (6), 614-629.

- Hand, M. (2018). Reasonable Disagreement about Morality (Chapter 1). In: Hand, M. (Ed.). A Theory of Moral Education (9-28). London: Routledge.

- Hand, M. (2008). What should we teach as controversial? A defence of the epistemic criterion. Educational Theory, 58 (2), 213-228.

- Harris, R. (2005). Does differentiation have to mean different? Teaching History, 118, 5-12.

- Hayward, J. (2007). Values, beliefs and the citizenship teacher. In: Gearon, L. (Ed.). Starting to teaching citizenship in the secondary school (37-54). Oxon: Routledgefalmer.

- Haydon, G. (2006). Respect persons and for cultures as a basis for national and global citizenship. Journal of Moral Education, 35 (4), 457-471.

- Hess, D. E. (2009). Controversy in the Classroom: The Democratic Power of Discussion. Oxon: Routledge.

- Hess, D. \& Gatti, L. (2010). Putting Politics Where It Belongs: In the Classroom. New Directions for Higher Education, 152, 19-26.

- Jerome L., Hayward J., Easy J. \& Newmanturner, A. (2003). The Citizenship Co-ordinator's Handbook. Cheltenham: Nelson Thornes.

- Karn, A. (2012). Toward a Philosophy of Holocaust Education: Teaching Values without Imposing Agendas. The History Teacher, 45 (2), 221-240.

- Kelly, T. (1986). Discussing controversial issues: four perspectives on the teacher's role. Theory and Research in Social Education, 14 (2), 113-138. 
- Kinloch, N. (2001). Parallel catastrophes? Uniqueness, redemption and the Shoah. Teaching History, 104, 8-14.

- Kitson, A., Husbands, C. \& Steward, S. (2011). Teaching and Learning History 11-18: Understanding the Past. Maidenhead: Open University Press.

- Landau, R. (1989). No Nazi war in British history?. Jewish Chronicle, 25, 1-20.

- Lee, P., Slater, J. \& Walsh, P. (1992). The Aims of School History: The National Curriculum and Beyond. London: The Tufnell Press.

- Lee, P. \& Shemilt, D. (2009). Is any explanation better than none? Over-determined narratives, senseless agencies and one-way streets in students' learning about cause and consequence in history. Teaching History, 137, 42-49.

- Levine, P. L. (2007). From Archive to Classroom: Reflections on Teaching the Holocaust in Different Countries. In: Goldenberg, M. \& Millen, R. L. (Eds.). Testimony, Tensions, and Tikkun: Teaching the Holocaust in Colleges and Universities (117-119). Seattle, WA: University of Washington Press.

- McCully, A. (2006). Practitioner perceptions of their role in facilitating the handling of controversial issues in contested societies: a Northern Irish experience. Educational Review, 58 (1), 51-56.

- Mercier, H. \& Sperber, D. (2011). Why do humans reason? Arguments for an argumentative theory. Behavioural and Brain Sciences, 34, 57-111.

- Miller-Lane, J., Denton, E. \& May, A. (2006). Social studies teachers' views on committed impartiality and discussion. Social Studies Research and Practice, 1 (1), 30-44.

- Novick, P. (1999). The Holocaust in American Life. New York: Houghton Mifflin Co.

- Oulton, C., Day, C., Dillon, J. \& Grace, J. (2004). Controversial issues- teachers' attitudes and practices in the context of citizenship education. Oxford Review of Education, 30 (4), 489-507.

- Pettigrew, A., Foster, S., Howson, J., Salmons, P., Lenga, R.-A. \& Andrews, K. (2009). Teaching about the holocaust in English Secondary Schools: An Empirical Study of National Trends, Perspectives and Practice. London: Holocaust Education Development Programme, Institute of Education, University of London.

- Reiss, M. J. \& White, J. (2014). An aims-based curriculum illustrated by the teaching of science in schools. The Curriculum Journal, 25, 76-89.

- Salmons, P. (2010). Universal meaning or historical understanding? The Holocaust in history and history in the curriculum. Teaching History, 141, 57-63.

- Slovic, P. (2007). 'If I look at the mass, I will never act': Psychic Numbing and Genocide. Judgment and Decision Making, 2 (2), 75-79.

- Siegel, H. (1997). Rationality Redeemed? Further Dialogues on an Educational Ideal. London: Routledge.

- Siegel, H. (1988). Educating Reason: Rationality, Critical Thinking and Education. London: Routledge.

- Short, G. (2003). Lessons of the Holocaust: A Response to the Critics. Educational Review, 55 (3), $277-287$.

- Stone, D. (2004). The Historiography of the Holocaust. New York.

- Totten, S. \& Feinberg S. (2016). Essentials of Holocaust Education: fundamental issues and approaches. New York: Routledge.

- Totten, S. (2001). Teaching Holocaust Literature. Boston, MA: Allyn and Bacon. 
- Walton, D. N. (1990). What is Reasoning? What Is an Argument? The Journal of Philosophy, 87 (8), 399-419.

- Woodcock, J. (2005). Does the linguistic release the conceptual? Helping Year 10 to improve their causal reasoning. Teaching History, 119, 5-14.

- Woodcock, J. (2011). Causal explanation. In: Davies, I. (Ed.). Debates in History Teaching (124-136). London: Routledge.

- Young, M. (2013a). Overcoming the Crisis in Curriculum Theory: A Knowledge-Based Approach. Journal of Curriculum Studies, 45 (2), 101-118.

- Young, M. (2013b). Powerful Knowledge: An Analytically Useful Concept or Just a 'Sexy Sounding Term’? A Response to John Beck's Powerful Knowledge, Esoteric Knowledge, Curriculum Knowledge. Cambridge Journal of Education, 43 (2), 195-198.

- Young, M. (2016). What are schools for? In: Young, M. \& Muller, J. (Eds.). Curriculum and the Specialisation of Knowledge: Studies in the Sociology of Education (105-115). London: Routledge.

- Young, M \& Muller, J. (2014). On the Powers of Powerful Knowledge. In: Barrett, B. \& Rata, E. (Eds.). Knowledge and the future of the curriculum: international studies in social realism. New York: Palgrave Macmillan. 


\section{Данило Д. Ковач}

\section{Универзитиети Сайијенц,а, Филозофски факулйей \\ Рим, Ийалија}

\section{О ОТВОРЕНИМ ПИТАҢИМА У НАСТАВИ ХОЛОКАУСТА}

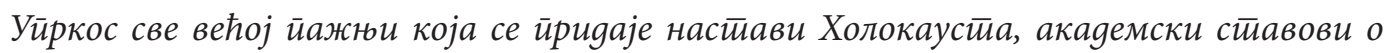

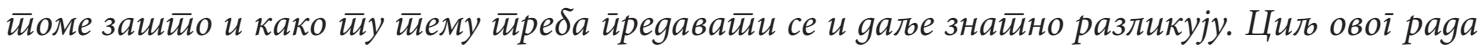

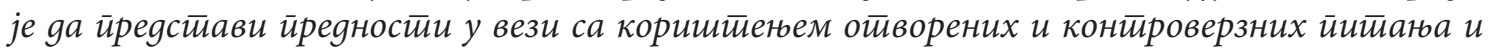
истиоријских йема као основа за йоgучаване Холокаустиа. У раgу су изложени аріумениии

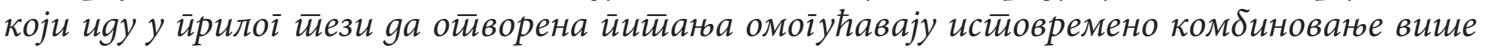

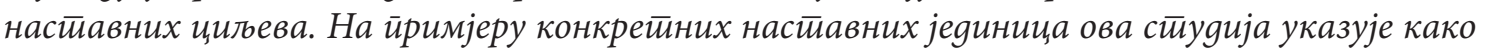

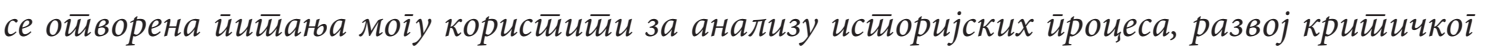

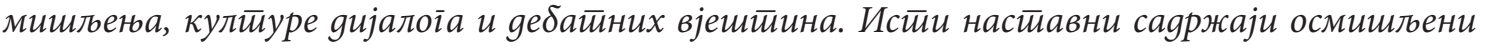

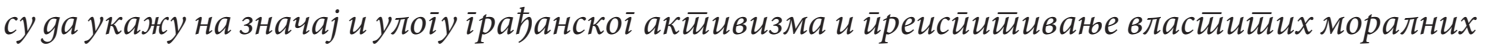

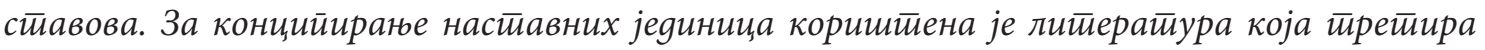

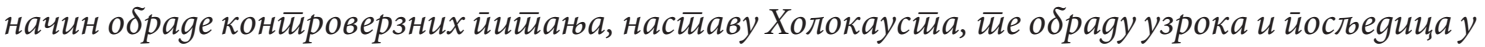

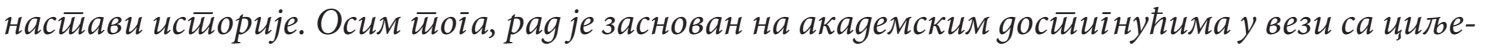
вима образовань у ширем смислу.

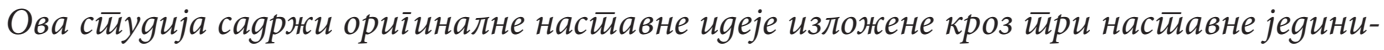
це, оg којих је свака заснована на йо јеgном ойвореном йитиану. Прва од них усмјерена је на gискусију о моіуућностии йрецизнијеі оgређивана и ияенйификације іранице између хероја,

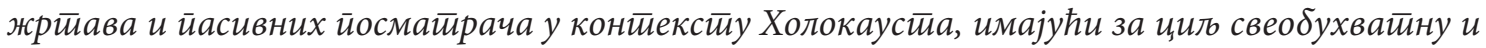
комйлексну анализу неких оg кључних йермина везаних за Холокаусти. Преgвиђено је gа се истиоријско знане као основа дойуни кроз gвије нареgне настиявне јеgинице, ийо је йраћено йосиичиним увођенем сложенијих соииолошких и филозофских концейайа. На йај на-

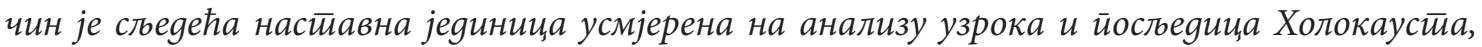
имајући на уму ойворена иитиаға юихове хијерархије и класификације. Постеgюа

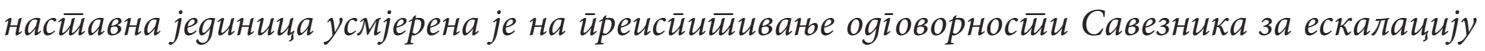

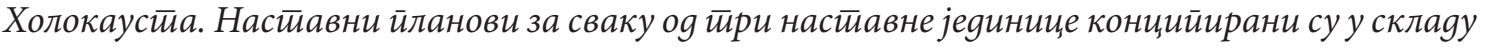

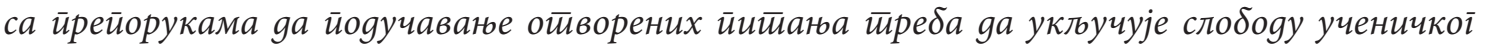

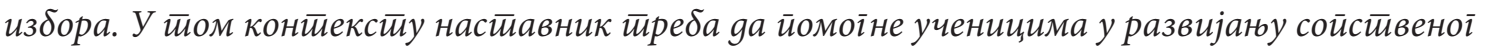

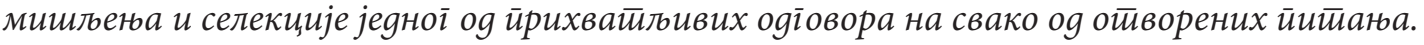

Настиавни саяржај изложен у овом раgу је осмишљен йако gа, йолазећи оg свакояневної знаюа, ученике йоgстичче на анализу истиоријских йроцеса и чињеница, али и

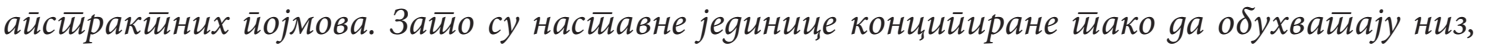

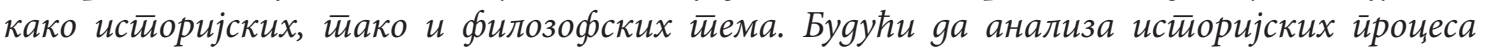




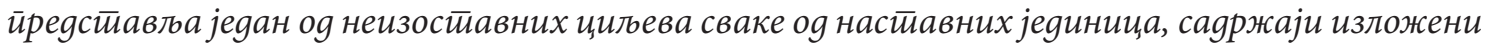
у овом раяу најӣримјеренији су за часове истиорије. Међуйим, мноїе оg ияеја йоїоgне су за

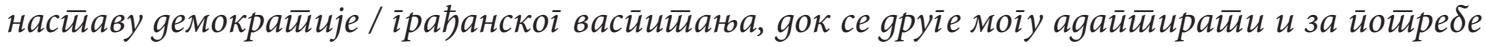

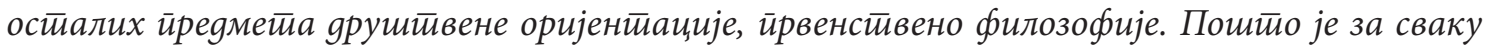

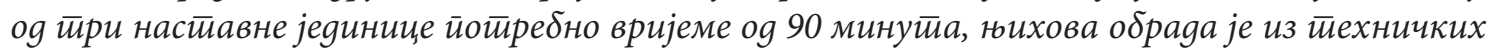

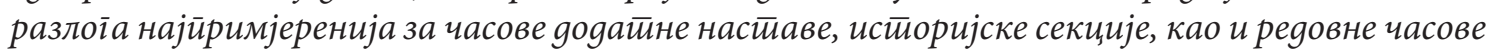
исӣорије у йроіраму Међународне матиуре.

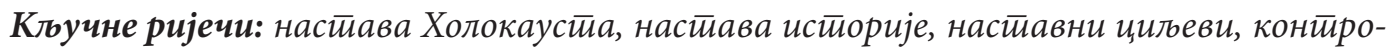
верзне иемее, ойворена йийана. 